\title{
Outdoor recreation
}

\section{Sites to help you plan your summer vacation}

\author{
by Shaun Spiegel
}

A mericans love the great outdoors, and they are looking more and more to the Internet for information on planning trips, choosing campsites, or checking out the latest gear. The National Park Service gathers visitation statistics for all areas they administer, and according to a National Park Visitor Use Summary, there were $287,130,879$ recreation visits in 1999 alone. $^{1}$

The following list of Web resources offers information on various outdoor recreational activities. The sites include commercial and governmental gateway sites as well as individual sites developed by enthusiasts of a particular outdoor sport or activity. Most cover U.S. locales, although a few include international information.

\section{Electronic Publications/E-zines}

- Cyberwest Magazine. Cyberwest Magazine provides information on outdoor recreation in the western United States. Click on a particular state to see Cyberwest articles, a recreation guide with information on various parks and recreational sites in the area, and state

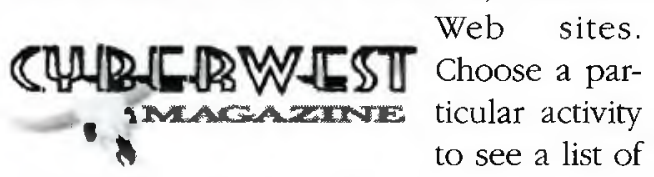
articles, Web sites, and other information relevant to that sport. The site also contains photographs and an archive of previous issues. Much of the content is based on the Great
Outdoor Recreation Pages (a link is provided to GORP at the bottom of the page). Access: http://www.cyberwest.com/.

- DesertUSA Magazine. This Web site features the current issue of DesertUSA Magazine, published by Digital West Media, Inc. Focusing on the American Southwest, this e-zine provides information on parks and monuments, recreation and wilderness areas, cities, towns, historic sites, and other points of interest. Also included are articles on various activities, as well as desert maps and information on the geology and environment of the desert. The Site Guide link at the bottom of the page is a great place to start; it explains how to navigate the site, gives complete content descriptions of each menu option, and provides submission guidelines to the magazine. Previous issues of the magazine are available from the site index. Access: http://www. desertusa.com/.

- Adventurezine Magazine. Adventurezine features information for campers and RV vacationers. Included are articles on vacation spots, a campground directory, and a list of other publications, including $M O A B$ Offroad, SUV OnLine, and $R V$ Video Magazine. Two notable sections are the Camping Ideas section, providing how-to camping tips such as "Building a Fire" or preparing "Crisp Camp Bacon," and Adventure Sports, providing links to Web sites for outdoor activities such as fishing, biking, and snow-

\section{About the author}

Shaun Spiegel is business and economics librarian at Weber State University in Ogden, Utah, e-mail: sspiegel1@weber.edu 
mobiling. Information on publishing in Adventurezine is presented in the Editorials section. Access: http://wow adventurezine. com.

Numerous online publications cover outdoor recreation. A few others include Mountain Zone (Access: http://www.mountainzone. com), which covers mountain-related activities, and Outside Online (Access: http://www. outsidemag.com), the online version of Outside magazine.

\section{Great starting points}

- Great Outdoor Recreation Pages (GORP). Whether you are a thrill-seeker or prefer a more sedentary vacation, GORP contains a wealth of information on what to do and where to go outdoors. Search for information on a specific destination (by city, state, park, or worldwide) or activity, or locate information on gear, books and maps, or travel resources. Each activity features information on where to go, how-to's, gear guides, and other relevant links. Destinations include both U.S, and international recreation spots for all activities. Access: http://www.gorp.com/.

- Recreation.gov. This user-friendly site claims to be the "one-stop source for information about recreation on federal lands." Choose a state from the pull-down menu, select activities or features of interest, and click the search button. The advanced search option also allows searching by agency (National Park Service, USDA Forest Service, etc.). Each entry lists basic contact information and driving directions, recreational activity options, a link to the area's Web site (if available), a National Weather Service forecast, and an atlas. Access: http://www.recreation.gov/.

- Groth and Marley Backpacking, Rafting, and Adventure Home Page. Authored by Susan and Robert R. Marley, this site is geared toward "self-reliant outdoors enthusiasts who wish to know more about non-commercial, low-cost travel opportunities created by like-minded folks." The site offers travel information on backpacking, rafting, and camping. The trips discussed are mainly 7 to 14 daylong outdoor camping-oriented trips. This Web site includes information on menu-planning software for private trips, Grand Canyon private rafters, tips on rafting trips, and reviews of the private rafting permit system. Also included is information on foreign travel to Costa
Rica, New Zealand, and Mexico, and hiking, backpacking, and climbing in the southwestern United States. Access: http://www.kwagunt. net/.

- Away.com. Away.com is a vacationplanning/travel agent that focuses on more exotic activities, such as cycling coast to coast in the Dominican Republic or excavating a Mayan ruin. Choose from location, activities (including beaches, horseback riding, art and culture, or safaris), or trip package (includes budget, cultural, family, senior, or solo packages). Services include a customer service center to answer calls or e-mails and to help book trips. An 800 number is provided for those who would rather book trips via telephone. Access: http://www.away.com/.

\section{Parks and camping}

- National Park Service (NPS). One useful feature of this excellent site is the Visit Your Parks link, which allows users to search for a particular park geographically, alphabetically, or by activity. Each entry gives basic information, quick facts, and an in-depth link for those who want more information. NPS also includes an online reservation service for national parks; information on national park passes, which can be purchased from the site; and park volunteer opportunities. Access: http://www.nps. gov.

- Park Search. Presented by L.L. Bean, Park Search provides information on parks and outdoor recreation areas worldwide. The userfriendly main page offers a search engine to search for parks by name and an image map to search a particular region of the world. Users may further narrow the search by specific region, area, or outdoor activity. Each entry contains a short description of the park and notes facilities offered for activities such as camping, hiking, fishing, hunting, water sports, cycling, winter sports, birdwatching, and others. Basic contact information is also provided, including address, telephone and fax, fee information, and a map. Access: http://www. llbean.com/parksearch/.

\section{Expanded version online}

An expanded version of this article is available on the Web at CERLNewsNet (http://www.ala.org/acrl/c\&rlnew2.html). 


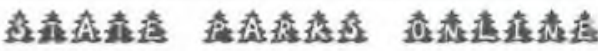

- State Parks Online. Compiled by Doug Dickson, this site presents information on state parks and reservoirs in the United States, current fees, camping and lodging information, recreation programs, and special events. Most links are maintained by the state departments of tourism or natural resources. An interactive map of the United States and an alphabetical listing of states is provided, as well as links to "additional park-related resources," listing various outdoor recreation links. Also included are links to regional and international parks, including a link to "Canadian provincial parks," featuring an interactive map of Canada, an alphabetical geographic listing, and other Canada park Web sites. Access: http://members. home.com/state-parks-online/.

- Camp-A-Roo: Camping and Hiking Information with Tips for Parents. This site is authored by Mary Boulding and focuses on family camping and hiking. Tips are included for many items such as camping equipment, activities, pet safety, product reviews, recipes, and great places to camp. Access: http://www. camp-a-roo.com/.

Many camping sites on the Web have somewhat incomplete listings. It is a good idea to check a few before making a decision on where to stay. For more information on camping and recreational vehicles, try Go Camping America! (Access: http://www.gocampingamerica.com/ main.html) or the Internet Camping Directory (Access: http://www.rvpark.com/).

\section{Climbing}

- Big Wall Climbing. Compiled by John Middendorf, this site presents information on climbing large rock faces and includes tips on clubs, equipment, and difficulty ratings. Also included are stories and information on specific climbing locations, organizations, essays, and photographs. Access: http://www. primenet.com/ midds/.

- Climbing Guide. This great resource is designed for both beginner and experienced climbers. The best place to start is "The Climbing Guide." This section provides a wealth of information on climbing, including what climbing actually is, who should or shouldn't climb, what to do before climbing, the differences between indoor and outdoor climbing, and various climbing techniques. The equipment link provides a nice introduction to climbing equipment, what it is used for, and descriptions. The site also contains a glossary and a site search engine. Access: http://library. thinkquest.org/13779/.

\section{Hiking}

- American Hiking Society (AHS). Based in Washington, D.C., the AHS is a nonprofit organization dedicated to promoting hilking and to establishing and protecting foot trails in America.

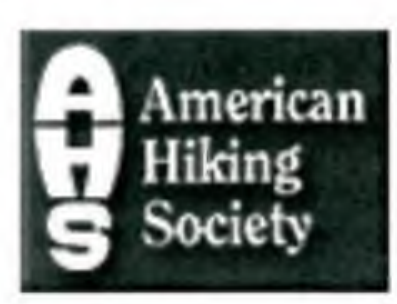

Noteworthy links include the AHS Hiker's Information Center, offering information on hikes, trail maps, volunteer opportunities, and clubs and organizations in the United States via a clickable map; and the Hiker's Emporium, which provides information on hiking gear, trail guides, and maps. The site also includes information on membership, society programs and activities, and links to AHS-affiliated clubs. Access: http://www. americanhiking.org/.

- Backpacking and Hiking Trailhead. A great resource for anyone considering a backcountry hiking and camping trip, this site presents a list of general hiking and backpacking pages. Included is information on bear safety, outdoor safety and wilderness survival, and backpacking tips, such as packing light, leaving no trace, how to navigate with a map and a compass, and recipe ideas. Access: http://www.geocities.com/Yosemite/Falls/ 9200/backpacking_and_hiking.html.

\section{Biking}

- BikeCrawler: Cycling Search Engine. Presented by LanzaTech, Inc., this site offers a search engine and directory of bicycling information. The site is easy to use and is broken down into categories such as apparel, clubs, manufacturers, news and media, organizations, racing, shops, software, special needs, training, and vacations and tours. Categories are broken down by geographic area and provide an annotated list of resources. Access: http://www. bikecrawler.com/.

- Cycling Related Pages on www. This user-friendly meta site is compiled by Jack Vinson. Divisions of the site include bicycle 
clubs, professional cyclists, cycling businesses and organizations, racing teams, race results, cycling publications, tandem-specific sites, and regional information. Each section contains an alphabetic listing of related Web sites, some with very brief annotations. Access: http://www.cis.upenn.edu/ vinson/ cycling.html.

- The MtbREVIEW. Notable sections of the MtbREVIEW include Product Reviews, all submitted by bikers, and Trail Reviews, which include more than 18,000 reviews on more than 3,700 trails around the world. In addition, there is a "Used Marketplace" for used bikes, parts, and accessories; races and events information; a chat room; and a search engine for reviews. Access: http://www.mtbr.com/.

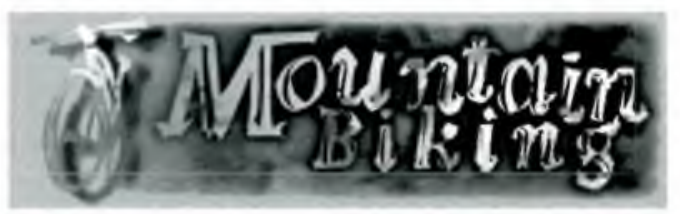

- Mountain Biking. This site is authored by computer science professor and mountain bike enthusiast Ross Finlayson. He provides information on mountain biking trails, events, and groups in the San Francisco Bay area as well as throughout the United States, Canada, Europe, Asia, and New Zealand. The site offers race information, riding and mechanical advice, photos, and general mountain biking information. Access: hitp://xenon.stanford.edu/ $\sim \mathrm{rsf} / \mathrm{m}$ tn-bike.html.

\section{Skiing}

- Snowlink.com. This user-friendly site offers information on skiing, snowboarding, cross-country skiing, and snowshoeing. The Gear link provides information on equipment, clothing, and accessories for specific snow sports, and tips for buying and renting. "Learn and Improve" offers information to those who are learning the sport, improving their skills, or looking for books or Web resources on snow sports. Select "News and Research" for statistics, facts, a history of snow sports, and consumer and industry news. A search engine for the site is provided on the main page. Access: http://www.snowlink.com/.

- SnoCountry Mountain Reports. SnoCountry presents information on the latest snow conditions, mountain resort information, and ski resort events. Choose a state, region, or country to obtain information on the resorts or detailed snow conditions for that area, including surface conditions, number of lifts operating, and average base depth. The menu includes the above options plus weather reports from various ski areas around the country. Choose "Nordic Center" to find out conditions for tele-mark, cross-country, heliskiing, and Snowcat skiing. Select the vacation planning link for tips on planning a ski vacation and the equipment center link for pointers on purchasing various types of ski equipment, with short descriptions and recommendations. Access: http://www.snocountry.com/.

- GoSki.com. GoSki offers a comprehensive directory of ski resorts in 35 countries and includes information on the resorts, gear, weather, news, and a ski vacation planner. The index provides a listing of all areas of the site in alphabetical order. Skiers may submit their own reviews of resorts and gear. Access: http://www.goski.com/.

\section{Outdoor resources for specific interest groups}

- International Gay and Lesbian Outdoor Organizations Network (IGLOO). IGLOO is an international network of gay, lesbian, and bisexual outdoor organizations. Select a state or international area from the clickable map on the main page to see a list of GLB groups, including telephone, address, and a link to their homepage, if available. Other notable links include a link to the Chiltern Mountain Club, which claims to be one of the largest GLB sports organizations; a miscellaneous link, with assorted tips such as trip etiquette or what to bring on a backpack trip; and a Web link, providing links to other organizations' homepages. Access: http://www. chiltern.org/chiltern/igloo.html.

- Disabled Sports USA. DSUSA is a national nonprofit organization started by disabled veterans in 1967 to provide sports and recreation services to children and adults with physical disabilities. Each community-based chapter offers various recreational programs, a few of which include snow and water skiing, sailing, kayaking, cycling, climbing, horseback riding, and golf. Links includes a schedule of events; information on competitive summer

\section{IDisabled Sports USA}


and winter programs and training camps; a chapter listing for each state; and a legal information page providing information on the Americans with Disabilities Act and Amateur Sports Act. The Athlete Highlight features short biographies of disabled athletes who have overcome their disabilities to perform amazing feats. Access: http://dsusa.org/.

\section{Watersports}

- Riversport.com. Riversport.com presents information on canoeing, kayaking, rafting, and other river sports throughout the United States. Notable features include the Online River Guide, which provides information on trips, guides, clubs and organizations, safety, river camping, and other riverrelated topics. The guide is searchable by keyword or location. The Paddler's Choice Mall provides information on clothing and gear, and is searchable by keyword or category. Access: http://www.riversport.com/

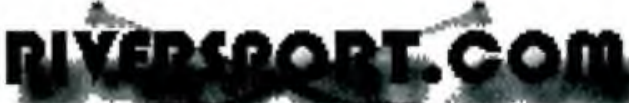

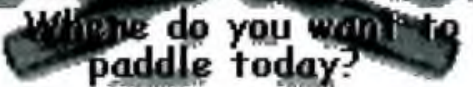

- Scuba Central. A notable division of this site is Rick's Links, a collection of more than 2,000 diving links, e-mail lists, and FTP sites, presented in alphabetical order by category. Another useful section is About Diving, a free online magazine containing special-interest articles on topics such as dive instruction, photography, technical diving, and equipment. Other sections include Scuba Humor, Shopping, a Photo Gallery, and an Industry Guide. This useful guide includes a searchable database listing dive retailers, charter operators, resorts, training agencies, underwater equipment manufacturers and retailers, instructors, and clubs and organizations, to name a few Inclusion in the guide is free. At present, there are not many listings, but this section has great potential. Access: http://www. scubacentral. $\mathrm{com} /$.

- Sporting Adventures LaunchPad. The SPAV Web site began in 1995 and is devoted to raising funds for conservation groups worldwide. This fishing and hunting site contains information on lodges and guides, a photo library, classifieds, regional information, field guides, and a fishing and hunting directory.

\section{SPORTNG Wu}

The Lodges and Guides database is searchable by state, species, and sport, and includes information on more than 3,000 resorts and lodges specializing in hunting and fishing. This site also includes links to other fishing, hunting, camping, parks, and outdoor sports sites. Information is also provided on SPAV membership, which is free. Access: http://www. spav.com/.

\section{Note}

1. The National Park Visitor Use Summary is on the Web at http://www2.nature.nps.gov/ stats/summary99.pdf.

("Faculty rank . . ." cont. from page 511)

\section{Role of the librarian still evolving}

Regardless of the controversy over the role of librarians in the academic community, it is clear that many librarians are receiving the rights and responsibilities of faculty status. As librarians' roles on campus continue to evolve, it is possible that certain conditions of faculty status may be seen as more or less appropriate for librarians. According to the ACRL statistics, the academic community has already agreed that librarians should receive research funding and academic freedom. But these institutions also have been slower to provide librarians with tenure and salaries that are equivalent to other faculty. By analyzing these data, academic librarians can gain a more complete picture of the state of the profession with regard to the criteria that define academic status.

\section{Notes}

1. "ACRL Guidelines for Academic Status for College and University Libraries," 1990. Available online at http://www.ala.org/acrl/ guides/acstatus.html.

2. Bede W. Mitchell and Bruce Morton, "On Becoming Faculty Librarians: Acculturation Problems and Remedies," College and Research Libraries 53, no. 5 (Sept. 1992): 389.

3. Blaise Cronin, "The Mother of All Myths," Library Journal 126, no. 3 (Feb. 2001): 144. 


\section{The SPARC/ACRL Forum}

\section{ALA San Francisco 2001}

Saturday, June 16, 2001

11:00 am-12:30 pm

\section{OUTWARD}

\section{Effecting Change in Scholarly Communication from Outside the Library}

- Faculty activists discuss their role within the discipline

- Provosts and administrators speak out

- Researchers present grassroots community models

In this session, attendees will interact with speakers whose commitment to change in scholarly communications takes place outside of the library context. Speakers will relate their experience from a faculty, provost, and researcher perspective while suggesting the most successful ways to reach out to those communities and build constituencies.

For more information: wwww.arl.org/sparc 